\title{
SYNCHRONOUS CULTURE OF CHLORELLA WITH SPECIAL REFERENCE TO THE PROCESSES OF ASSIMILATION OF POTASSIUM, MAGNESIUM AND IRON
}

\author{
TAMOTSU KANAZAWA \\ The Tokugawa Institute for Biological Research, Tokyo \\ Received for publication March 11, 1958
}

\section{INTRODUCTION}

The study of physiological and biochemical processes occurring in the life cycle of Chlorella has been greatly facilitated since the technique of synchronous culture of the alga was developed in our laboratory (1-4). By elaboration of the technique we are now able to analyse the life cycle of algal cells into the following seven successive stages (see Fig. 1).

(a) "Nascent dark cells" $\left(D_{n}\right)$, which are the young cells newly produced from mother cells.

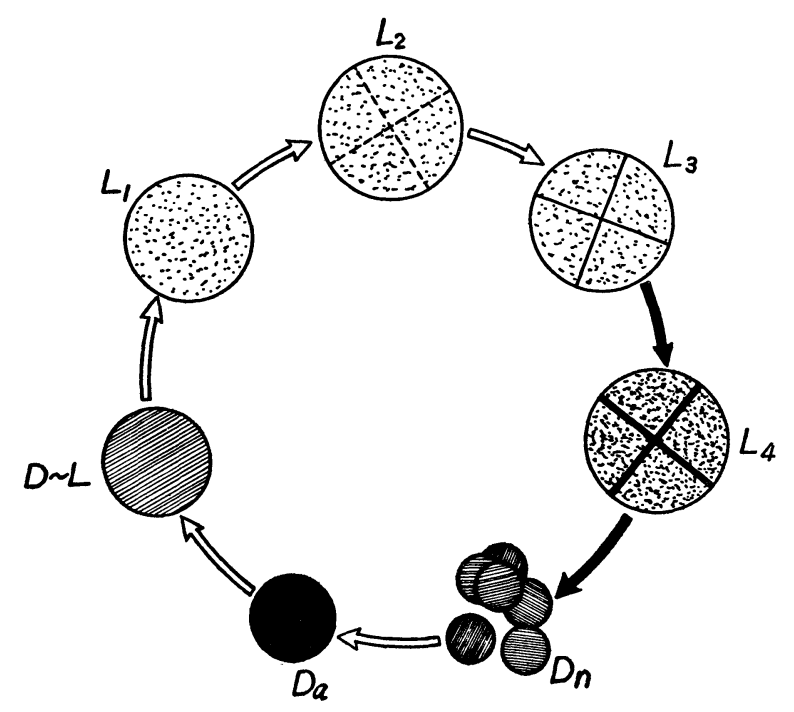

Fig. 1. Schematic representation of the life cycle of Chlorella. White arrows indicate the light processes, while black arrows show the processes that can occur independently of light. Sizes of circles correspond approximately to the relative sizes of cells and the extent of darkening indicates the relative photosynthetic activity. 
(b) "Active dark cells" $\left(D_{a}\right)$, the most chlorophyll-rich and photosynthetically active cells which are derived from $D_{n}$ when illuminated.

(c) Cells of transient stage between dark and "light" cells $(D \sim L)$.

(d) "Immature light cells" $\left(L_{1}\right)$, which are large in size, but not yet ripe enough to perform cell division when incubated in the dark.

(e) "Half-mature light cells" $\left(L_{2}\right)$, which can only partially divide when kept in the dark.

(f) "Mature light cells" $\left(L_{3}\right)$, which can completely divide when kept in the dark.

(g) "Fully ripened light cells" $\left(L_{4}\right)$, which are at the stage immediately prior to the process of cell division.

It was observed $(3,4)$ that the cells at these different stages show more or less different contents in nitrogen, phosphorus, sulphur as well as in crude proteins, lipids, carbohydrates, nucleic acids, chlorophyll, etc. The present experiments were performed with the view to examine whether and in what manner the contents of algal cells in potassium, magnesium and iron will change during the course of their life cycle.

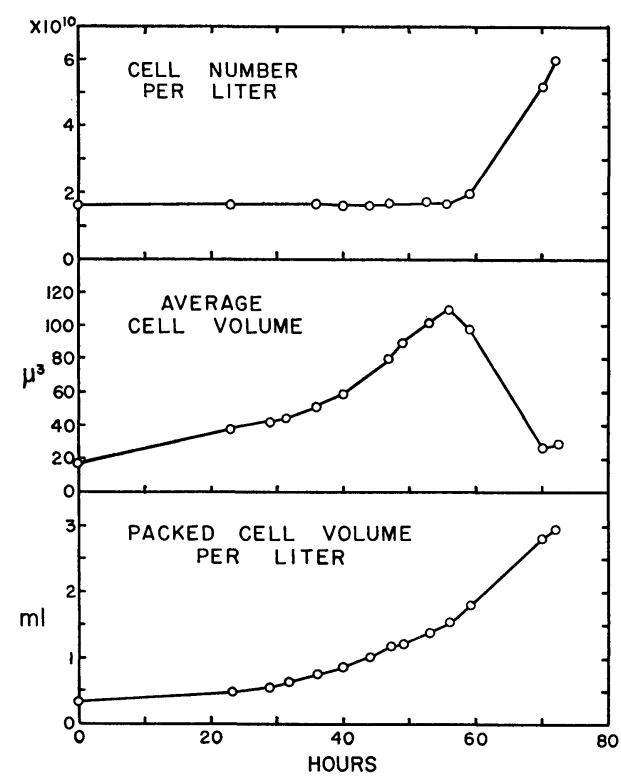

Fig. 2. An example of synchronous culture of Chlorella starting from "active dark cells". Illumination: 10 kilolux. Temperature: $15^{\circ}-16^{\circ}$.

\section{METHODS}

The experimental organism was Chlorella ellipsoidea, and the culture methods employed were virtually the same as those reported previously $(3,4)$. The preultures were run at $20^{\circ}-25^{\circ}$ under illumination with daylight fluorescent lamps of 8-10 kilolux in intensity, and the subsequent synchronous culture starting from "active dark cells" was conducted at $15^{\circ}-16^{\circ}$ under illumination with a series of daylight fluorescent lamps, about 10 kilolux in intensity at the surface of the culture. The culture medium used was of the following composition: per liter, $\mathrm{KNO}_{3} 5.0 \mathrm{~g}, \mathrm{MgSO}_{4} \cdot 7 \mathrm{H}_{2} \mathrm{O} 2.5 \mathrm{~g}$, $\mathrm{KH}_{2} \mathrm{PO}_{4} 1.25 \mathrm{~g}, \mathrm{FeSO}_{4} \cdot 7 \mathrm{H}_{2} \mathrm{O} 0.003$ g, Arnon's “A5" solution $1 \mathrm{ml}(5)$. During the experiment the cultures were constantly aerated with

air containing 5 percent $\mathrm{CO}_{2}$. The process of cell development was followed by measuring: (i) the number of cells per liter (using a hemacytometer), (ii) 
the statistical distribution of cell size (by means of an ocular micrometer), and, (iii) the packed volume of cells per liter (using a hematocrit). An example of the data of synchronous culture is presented in Fig. 2. In this case the cell division began at the 59th hour of the experiment and was completed within about 12 hours.

At various stages of synchronous culture, certain portions of cell sample were taken out, and after washing three times with distilled water, they were analysed for their dry weight, ash weight and cation contents using the following methods. The cells (about $100 \mathrm{mg}$ in dry weight) were dried to constant weight using infra-red lamps, and after being charred in an oven, kept in a muffle furnace at $450^{\circ}-480^{\circ}$ for 24 hours. When the ashing was incomplete, the sample was dissolved in a minimum quantity of concentrated nitric acid and heated again in the furnace. After completion of the ashing, the sample was dissolved in $1 \mathrm{ml}$ of concentrated hydrochloric acid, and passed through a column of Amberlite IRA 400 ( $3 \mathrm{ml}$ in volume) with subsequent scrubbing using $20 \mathrm{ml}$ of distilled water (at the velocity of $0.5 \mathrm{ml}$ per minute). The solution obtained was made up to $25 \mathrm{ml}$ in a volume flask, and subjected to the determination of $\mathrm{K}, \mathrm{Mg}$ and $\mathrm{Fe}$. Potassium and magnesium were determined by means of flame photometry (at $404.6 \mathrm{~m} \mu$ for $\mathrm{K}$ and $371 \mathrm{~m} \mu$ for $\mathrm{Mg}$ ) using the Beckman DU spectrophotometer. Determination of iron was conducted by application of the orthophenanthroline method (6).

\section{RESULTS}

Change in content of total ash. The total ash content of algal cells showed a characteristic change during the course of the life cycle. The data obtained at successive stages of cell development are presented in Fig. 3, in which the content is given both on the per cell basis and in percent of dry weight. For comparison, the change of dry weight of single cells is also shown in the figure. As may be seen, the ash content per cell remained almost unchanged at the stages from $D_{n}$ to $L_{1}$, and increased markedly at later stages $\left(L_{2}, L_{3}\right.$ and $\left.L_{4}\right)$. Since the weight of single cells increased

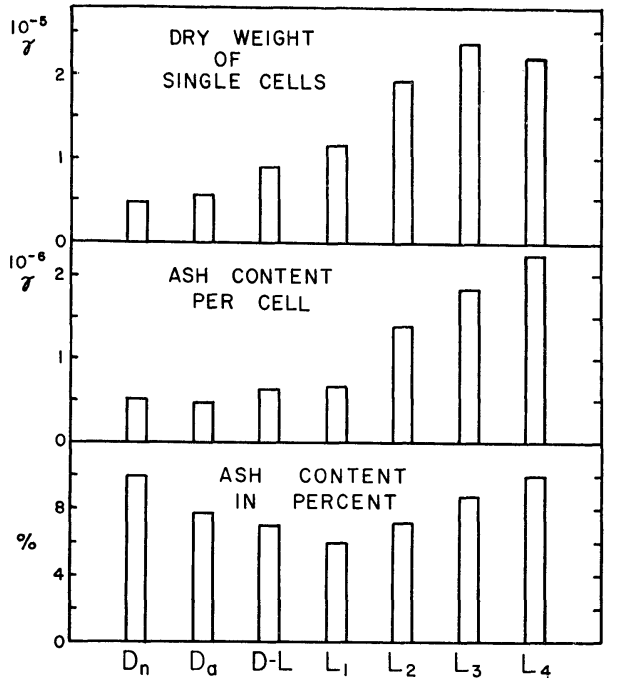

Fig. 3. Change of total ash content during the course of life cycle, as compared with the change of dry weight of single cells.

appreciably during the period from $D_{n}$ to $L_{1}$, the ash content in percent of cell substance showed a marked decrease during this period. The percentage 
was lowest (6.5 percent) at $L_{1}$ and highest (10 percent) at $D_{n}$ and $L_{4}$.

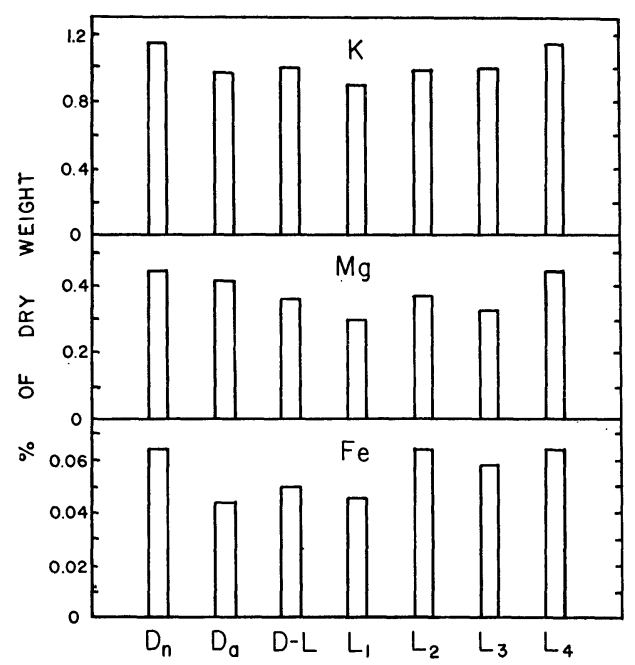

Fig. 4. Percentage (on a dry weight basis) of potassium, magnesium and iron as found in cells of different developmental stages.

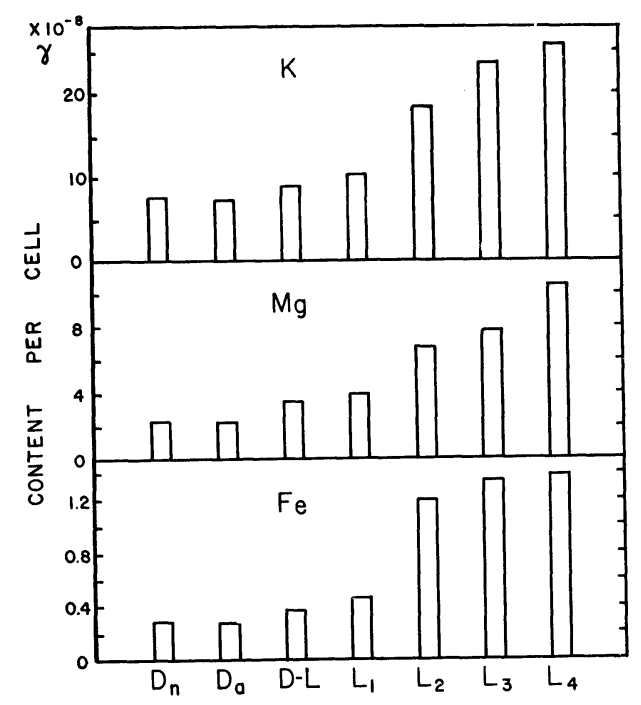

Fig. 5. Changes of contents (per cell) of potassium, magnesium and iron during the course of life cycle.

Changes in contents of potassium, magnesium and iron. Changes in contents of potassium, magnesium and iron are shown in Figs. 4 and 5, the contents being given in percent of dry weight and on the per cell basis, respectively. In terms of percentage of dry weight, the content of potassium remained relatively constant throughout the life cycle, indicating that the assimilation of potassium occurred almost keeping pace with the increase of total cell mass. On the other hand, the contents (in percent) of magnesium and iron decreased markedly during the stages from $D_{n}$ to $L_{1}$, and increased sooner or later during the later stages.

\section{DISCUSSION}

We have seen that potassium was assimilated by algal cells almost keeping pace with the photosynthetic assimilation of the bulk of cell material, whereas magnesium and iron were assimilated more in the ripening stage (the stage of light cells) than in the growing stage (the stages from $D_{n}$ to $L_{1}$ ). The role of potassium in the physiology of algal cells is at present still quite obscure. It may only be noticed here that the occurrence of process similar to that observed for the assimilation of potassium has thus far been observed also in the assimilation of nitrogen and in the formation of bulk protein and ribonucleic acid in algal cells $(3,4)$. 
On the other hand, the phenomenon similar to that observed in the assimilation of magnesium and iron, has been observed in the assimilation of sulphur and phosphorus and in the formation of desoxyribonucleic acid and chlorophyll $(1,3,4)$. It should also be remarked that the light cells are characterized in their stronger respiratory activity compared with dark cells (2). Needless to say, magnesium is an indispensable element in chlorophyll molecule and iron is a key element in the molecules of heme proteins which have been known to exist in close association with the photosynthetic apparatus in green cells. These considerations may give some clue to an understanding of the phenomenon that magnesium and iron are assimilated in larger measures by light cells than by dark cells.

The phenomenon that the content (in percent) of total ash dropped strikingly at the stages around $L_{1}$ is apparently due to the combined effects of the assimilation of magnesium, iron, sulphur and phosphorus, all of which are absorbed in lesser amounts in the growing stage than in the ripening stage.

\section{ACKNOWLEDGEMENTS}

This work was carried out as a part of the studies on the growth of Chlorella under the direction of Professor Hiroshi Tamiya, to whom the writer is indebted for his guidance. Thanks are also due to Dr. Eiji Hase for his helpful advice in the preparation of this paper. This work was aided by grants from the Ministry of Education and the Rockefeller Foundation. To these bodies we extend our grateful thanks.

\section{SUMMARY}

(1) By using the technique of synchronous culture of Chlorella, the changes in contents of potassium, magnesium and iron in successive developmental stages of algal cells were investigated.

(2) In percent of dry weight of cells, the content of potassium remained relatively constant throughout the life cycle, whereas the contents of magnesium and iron were lower at the growing stages (from the stage of "nascent dark cells" to the stage of "immature light cells") and higher at the ripening stage (the stages of light cells).

(3) A brief discussion was made in an attempt to relate the data obtained with earlier observations regarding the changes in contents of various other cell materials in the life cycle of Chlorella cells.

\section{REFERENCES}

(1) Tamiya, H., Iwamura, T., Shibata, K., Hase, E. and Nihei, T.: Biochim. Biophys. Acta, 12, 23 (1953). 
(2) Nihei, T., SaSa, T., MiYachi, S., SuzUki, K. and TamiYa, H.: Arch. Mikrobiol., 21, 155 (1954).

(3) Iwamura, T., Hase, E., Morimura, Y. and Tamiya, H.: Ann. Acad. Sci. Fennicae, Ser. A II, 60, 89 (1955).

(4) Hase, E., Morimura, Y. and Tamiya, H.: Arch. Biochem. Biophys., 69, 149 (1957).

(5) Arnon, D.: Amer. J. Bot., 25, 322 (1938).

(6) SANDELl, E. B.: Colorimetric Determination of Traces of Metals. Chemical Anal., III, Intersci. Publishers, Inc., New York, 1950. 